Communications in Physics, Vol. 28, No. 3 (2018), pp. 237-245

DOI:10.15625/0868-3166/28/3/12666

\title{
GROWTH OF SINGLE CRYSTALS OF METHYLAMMONIUM LEAD MIXEDHALIDE PEROVSKITES
}

\author{
THUAT NGUYEN-TRAN ${ }^{a}{ }^{\dagger}$, NGOC MAI AN ${ }^{a}$, THU TRANG LUONG ${ }^{b}$, \\ HUNG HUY NGUYEN ${ }^{b}$ AND THANH TU TRUONG $^{b}$ \\ ${ }^{a}$ Nano and Energy Center, VNU University of Science, \\ 334 Nguyen Trai, Thanh Xuan District, Hanoi, Vietnam \\ ${ }^{b}$ Faculty of Chemistry, VNU University of Science, \\ 19 Le Thanh Tong, Hoan Kiem District, Hanoi, Vietnam \\ ${ }^{\dagger}$ E-mail: thuatnt@vnu.edu.vn \\ Received 11 June 2018 \\ Accepted for publication 23 July 2018 \\ Published 31 August 2018
}

\begin{abstract}
We report the growth and characterization of different bulk single crystals of organo lead mixed halide perovskites $\mathrm{CH}_{3} \mathrm{NH}_{3} \mathrm{PbI}_{3-x} \mathrm{Br}_{x}$ by two different crystal growth approaches: (i) anti-solvent diffusion, and (ii) inverse temperature crystallization. In order to control the size and the shape of crystals, we have investigated different experimental growth parameters such as temperature and precursor concentration. The morphology of obtained crystals was observed by optical microscope, whereas their intrinsic crystalline properties were characterized by single crystal as well as powder X-ray diffraction. The results illustrated that the growth and crystalline structure of mixed halide perovskites $\mathrm{CH}_{3} \mathrm{NH}_{3} \mathrm{PbI}_{3-x} \mathrm{Br}_{x}$ could be easily tuned.
\end{abstract}

Keywords: Organo lead mixed halide perovskites, single crystal, $\mathrm{CH}_{3} \mathrm{NH}_{3} \mathrm{PbI}_{3-x} \mathrm{Br}_{x}$. Classification numbers: 61.05.C-; 81.05.Hd. 


\section{INTRODUCTION}

Until now, the power conversion efficiency of hybrid organo metal halide perovskite solar cells has significantly increased up to $20.1 \%$ [1]. These up-to-the-minute new devices surpassed other third-generation solar cells to become the most promising rival to the silicon-based solar cells due to their superiorities, such as high charge carrier motilities, low temperature (below $150^{\circ} \mathrm{C}$ ) solution process, extreme large carrier diffusion lengths, as well as the outstanding photovoltaic efficiencies [2-4]. Since the morphology of the perovskite $1 \mathrm{~m}$ is one of the most crucial factors to aect the performance of the device, many approaches have been developed for its improvement. Well-controlled morphology of the perovskite layer is a significant element to provide the device with high efficiency and high stability. In order to improve quality of the perovskite layer, various techniques have been reported such as additives, $[5,6]$ fast deposition-crystallization (anti-solvent dripping), [7,8] sequential deposition method [9], hot casting technique [10], nonstoichiometric perovskite precursor [11], and vapor-assisted annealing [12]. Since monocrystallinebased solar cells always possess the potential of yielding higher power conversion efficiency than multicrystalline-based ones, understanding the growth mechanism of perovskite crystallites has great benets for further improving the performance and enlightening us to exploit new technologies for large-scale and low-cost fabrication of perovskite solar cells. In this paper, we report the investigation of the growth and characterization of bulk single crystals of $\mathrm{CH}_{3} \mathrm{NH}_{3} \mathrm{PbI}_{3-x} \mathrm{Br}_{x}$ perovskites. The general morphology of the obtained single crystals was observed by optical microscope, whereas their crystalline structures were characterized by X-ray diffraction techniques.

\section{EXPERIMENTAL PROCEDURES}

\section{II.1. Preparation of Precursors $\mathrm{CH}_{3} \mathrm{NH}_{3} \mathrm{I}$ and $\mathrm{CH}_{3} \mathrm{NH}_{3} \mathrm{Br}$}

$\mathrm{CH}_{3} \mathrm{NH}_{3} \mathrm{I}$ was synthesized by the equimolar reaction between $\mathrm{CH}_{3} \mathrm{NH}_{2} 25$ wt. \% in ethanol and $\mathrm{HI} 57 \mathrm{wt} . \%$ in water at $0^{\circ} \mathrm{C}$ in $2 \mathrm{~h}$ under nitrogen purge. $\mathrm{CH}_{3} \mathrm{NH}_{3} \mathrm{Br}$ was synthesized by the equimolar reaction between $\mathrm{CH}_{3} \mathrm{NH}_{2} 25$ wt.\% in ethanol and $\mathrm{HBr} 40$ wt.\% in water at room temperature in $2 \mathrm{~h}$ under nitrogen purge. The crystallization of $\mathrm{CH}_{3} \mathrm{NH}_{3} \mathrm{I}$ or $\mathrm{CH}_{3} \mathrm{NH}_{3} \mathrm{Br}$ was carried out by rotary evaporation of the corresponding solutions. The obtained crystals were washed in diethyl ether, and then dried in vacuum at $60^{\circ} \mathrm{C}$.

\section{II.2. Preparation of $\mathrm{CH}_{3} \mathrm{NH}_{3} \mathrm{PbI}_{3-x} \mathrm{Br}_{x}$ Solutions}

In order to prepare the solution of $\mathrm{CH}_{3} \mathrm{NH}_{3} \mathrm{PbI}_{3}$ in gamma-Butyrolactone (GBL) $1 \mathrm{M}$, an equimolar mixture of $\mathrm{PbI} 2(2.305 \mathrm{~g})$ and $\mathrm{CH}_{3} \mathrm{NH}_{3} \mathrm{I}(0.795 \mathrm{~g})$ was diluted in GBL solvent by stirring. The mixture was then kept at $60^{\circ} \mathrm{C}$ for $3 \mathrm{~h}$ until the mixture became yellow and clear. Finally, the solution was transferred into a glass vial and kept at room temperature. The solution of $\mathrm{CH}_{3} \mathrm{NH}_{3} \mathrm{PbBr}_{3}$ in dimethylformamide (DMF) 1 Mwas prepared by similar way from an equimolar mixture of $1.835 \mathrm{~g} \mathrm{PbBr}_{2}$ (white powder), $0.56 \mathrm{~g} \mathrm{CH}_{3} \mathrm{NH}_{3} \mathrm{Br}$ (white crystal) and DMF solvent.

\section{II.3. Growth of $\mathrm{CH}_{3} \mathrm{NH}_{3} \mathrm{PbI}_{3-x} \mathrm{Br}_{x}$ Perovskitesingle Crystals}

For the growth of single crystals via the anti-solvent diffusion (ASD) method [13], $5 \mathrm{ml}$ of $\mathrm{CH}_{3} \mathrm{NH}_{3} \mathrm{PbI}_{3-x} \mathrm{Br}_{x}$ solutionwas filtered through a $0.2 \mu$ PTFE syringe filter and placed in a small open vial and then put into a bigger and sealed container with $7 \mathrm{ml}$ of dichloromethane (DCM),acting as anti-solvent. The experimental setup was kept overnight at room temperature 
and under normal atmospheric pressure. DCM, which is more volatile, was naturally evaporated, and diffused from the gaseous phase into the precursor solution, leading to supersaturation, then nucleation and finally crystallization. We can regulate the diffusion speed by varying the temperature. For the inverse temperature crystallization (ITC) method [14], $3 \mathrm{ml}$ of $\mathrm{CH}_{3} \mathrm{NH}_{3} \mathrm{PbI}_{3-x} \mathrm{Br}_{x}$ solutionwas filtrated through a $0.2 \mu \mathrm{m}$ PTFE syringe filter and placed into a sealed glass vial. The solution was then heated to $110^{\circ} \mathrm{C}$ in an oil bath until the first crystal appearance and kept for another $3 \mathrm{~h}$. These single crystals were then taken out with a spoon and kept in DCM for protecting from moisture.

\section{II.4. Characterization}

To determine the site and position of each atom in the perovskite unit cell, we used singlecrystal X-ray diffraction (SCXRD) measurement with Mo-K $\alpha$ radiation $(\lambda=0.71073 \AA)$. In parallel, we used powder X-ray diffraction (XRD) measurement, on a Bruker D8 Advance X-ray diffractometer with $\mathrm{Cu}-\mathrm{K} \alpha$ radiation $\left(\lambda=1.5418 \AA, 2 \theta\right.$ steps $=0.03^{\circ} /$ step $)$. General shapes and morphology of the obtained crystals was investigated by an optical microscope with different magnification.

\section{RESULTS AND DISCUSSION}

The general information of five different large bulk single crystals of $\mathrm{CH}_{3} \mathrm{NH}_{3} \mathrm{PbI}_{3-x} \mathrm{Br}_{x}$ $(x=0,1,2,2.75$ and 3$)$ is shown in Table 1 . The value of $x$, so called the preparation ratio, is calculated from the volume ratio of $1 \mathrm{M} \mathrm{CH}_{3} \mathrm{NH}_{3} \mathrm{PbI}_{3}$ solution in $\mathrm{GBL}$ and $1 \mathrm{M} \mathrm{CH}_{3} \mathrm{NH}_{3} \mathrm{PbBr}_{3}$ solution

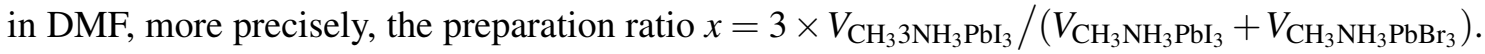
The color of synthesized single crystals changes from black, at $x=0$, to blackish brown, at $x=1$, to orange, at $x=2,2.75$, and 3 . The morphology of these large single crystals changed from parallelogram blocks, at $x=0$, to hexagonal one, at $x=1$, and cubic one, at $x=2,2.75,3$.

Table 1. The general information of single crystals of mixed halide perovskites.

\begin{tabular}{llccccc}
\hline $\begin{array}{l}\text { No. Preparation } \\
\text { formula }\end{array}$ & $\begin{array}{c}\text { Preparation } \\
\text { ratio } x\end{array}$ & $\begin{array}{c}\mathrm{CH}_{3} \mathrm{NH}_{3} \mathrm{PbI}_{3} / \\
\mathrm{CH}_{3} \mathrm{NH}_{3} \mathrm{PbBr}_{3}\end{array}$ & Color & $\begin{array}{c}\text { Bulk crystal } \\
\text { morphology }\end{array}$ & Size \\
\hline 1 & $\mathrm{CH}_{3} \mathrm{NH}_{3} \mathrm{PbI}_{3}$ & 0 & $3: 0$ & black & parallelogram & $0.5 \mathrm{~mm} \times 1 \mathrm{~mm}$ \\
2 & $\mathrm{CH}_{3} \mathrm{NH}_{3} \mathrm{PbI}_{2} \mathrm{Br}$ & 1 & $2: 1$ & dark brown & hexagonal & $1.5 \mathrm{~mm} \times 1.5 \mathrm{~mm}$ \\
3 & $\mathrm{CH}_{3} \mathrm{NH}_{3} \mathrm{PbIBr}_{2}$ & 2 & $1: 2$ & orange & cubic & $2 \mathrm{~mm} \times 2 \mathrm{~mm}$ \\
4 & $\mathrm{CH}_{3} \mathrm{NH}_{3} \mathrm{PbI}_{0.25} \mathrm{Br}_{2.75}$ & 2.75 & $1: 11$ & orange & cubic & $1.5 \mathrm{~mm} \times 1.5 \mathrm{~mm}$ \\
5 & $\mathrm{CH}_{3} \mathrm{NH}_{3} \mathrm{PbBr}_{3}$ & 3 & $0: 3$ & orange & cubic & $2 \mathrm{~mm} \times 2 \mathrm{~mm}$ \\
\hline
\end{tabular}

Fig. 1a illustrates that the color of crystals changes from orange color (for high content of bromide) to more and more blackish brown color when the content of bromide reduces. Fig. 1b shows that large single crystals with the size of about $2 \mathrm{~mm}$ to $3 \mathrm{~mm}$ have been successfully synthesized. 
Characterization using an optical microscope is a simple way to quickly observe the size, the shape, and the morphology of obtained single crystals. Fig. 2 shows the optical images of the single crystals of perovskites with preparation formulas: (a) $\mathrm{CH}_{3} \mathrm{NH}_{3} \mathrm{PbI}_{3}$, (b) $\mathrm{CH}_{3} \mathrm{NH}_{3} \mathrm{PbI}_{2} \mathrm{Br}$, (c) $\mathrm{CH}_{3} \mathrm{NH}_{3} \mathrm{PbI}_{0.25} \mathrm{Br}_{2.75}$, (d) $\mathrm{CH}_{3} \mathrm{NH}_{3} \mathrm{PbIBr}_{2}$ and (e) $\mathrm{CH}_{3} \mathrm{NH}_{3} \mathrm{PbBr}_{3}$.

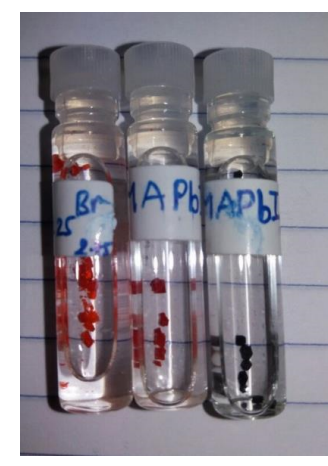

(a)

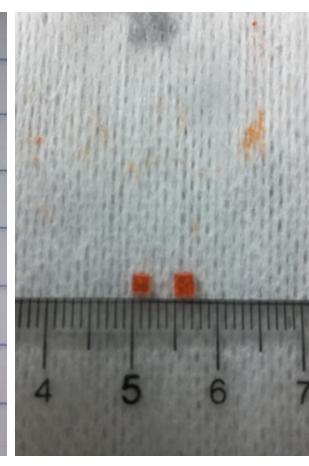

(b)

Fig. 1. (a) $\mathrm{CH}_{3} \mathrm{NH}_{3} \mathrm{PbI}_{3-x} \mathrm{Br}_{x}$ crystals with preparation ratio $x=2.75$, 2, to 1 (going from left to right) (b) $\mathrm{CH}_{3} \mathrm{NH}_{3} \mathrm{PbBr}_{x}$ crystal $(2 \mathrm{~mm} \times 2 \mathrm{~mm}$ ).

The sharp edges of the obtained crystal illustrate the uniform growth of those single crystals. When one iodide atom is replaced by one bromide atom in the perovskite unit cell, single crystals of $\mathrm{CH}_{3} \mathrm{NH}_{3} \mathrm{PbI}_{2} \mathrm{Br}$ are obtained with the dimension of $1.5 \mathrm{~mm} \times 1.5 \mathrm{~mm}$ in hexagonal shapes. As the content of bromide increased, the shape of the obtained crystals is more and more associated with the cubic shape as illustrated in Fig. 2c for the single crystal of $\mathrm{CH}_{3} \mathrm{NH}_{3} \mathrm{PbIBr}_{2}$ with the dimension of $2 \mathrm{~mm} \times 2 \mathrm{~mm}$.

Table 2. X-ray structure data collection and refinement parameter of single crystal perovskites with preparation formula $\mathrm{CH}_{3} \mathrm{NH}_{3} \mathrm{PbI}_{3}, \mathrm{CH}_{3} \mathrm{NH}_{3} \mathrm{PbI}_{2} \mathrm{Br}, \mathrm{CH}_{3} \mathrm{NH}_{3} \mathrm{PbI}_{0.25} \mathrm{Br}_{2.75}$ and $\mathrm{CH}_{3} \mathrm{NH}_{3} \mathrm{PbBr}_{3}$.

\begin{tabular}{|c|c|c|c|c|c|}
\hline \multicolumn{3}{|c|}{ Preparation formula $\mathrm{CH}_{3} \mathrm{NH}_{3} \mathrm{PbI}_{3}$} & $\mathrm{CH}_{3} \mathrm{NH}_{3} \mathrm{PbI}_{2} \mathrm{Br}$ & $\mathrm{CH}_{3} \mathrm{NH}_{3} \mathrm{PbI}_{0.25} \mathrm{Br}_{2.75}$ & $\mathrm{CH}_{3} \mathrm{NH}_{3} \mathrm{PbBr}_{3}$ \\
\hline \multicolumn{2}{|c|}{ Refined formula } & $\mathrm{CH}_{3} \mathrm{NH}_{3} \mathrm{PbI}_{3}$ & $\mathrm{CH}_{3} \mathrm{NH}_{3} \mathrm{PbI}_{1.69} \mathrm{Br}_{1.31}$ & $\mathrm{CH}_{3} \mathrm{NH}_{3} \mathrm{PbI}_{0.13} \mathrm{Br}_{2.87}$ & $\mathrm{CH}_{3} \mathrm{NH}_{3} \mathrm{PbBr}_{3}$ \\
\hline \multicolumn{2}{|c|}{ Crystal System } & tetragonal & cubic & cubic & cubic \\
\hline \multicolumn{2}{|c|}{ Space group } & $\mathrm{I} 4 / \mathrm{mcm}$ & Pm-3m & $\mathrm{Pm}-3 \mathrm{~m}$ & $\mathrm{Pm}-3 \mathrm{~m}$ \\
\hline \multicolumn{2}{|c|}{$\mathrm{Z}$} & 32 & 48 & 48 & 48 \\
\hline \multicolumn{2}{|c|}{ Volume $\left(\AA^{3}\right)$} & $999.34(15)$ & $229.73(5)$ & $209.55(5)$ & $208.63(6)$ \\
\hline \multirow{6}{*}{$\begin{array}{c}\text { Lattice } \\
\text { parameter }\end{array}$} & $\mathrm{a}(\AA)$ & $8.8850(6)$ & $6.1245(4)$ & $5.9397(5)$ & $5.931(1)$ \\
\hline & $\mathrm{b}(\AA)$ & $8.8850(6)$ & $6.1245(4)$ & $5.9397(5)$ & $5.931(1)$ \\
\hline & $\mathrm{c}(\AA)$ & $12.6590(9)$ & $6.1245(4)$ & $5.9397(5)$ & $5.931(1)$ \\
\hline & $\alpha\left(^{\circ}\right)$ & 90 & 90 & 90 & 90 \\
\hline & $\beta\left(^{\circ}\right)$ & 90 & 90 & 90 & 90 \\
\hline & $\gamma\left({ }^{\circ}\right)$ & 90 & 90 & 90 & 90 \\
\hline
\end{tabular}




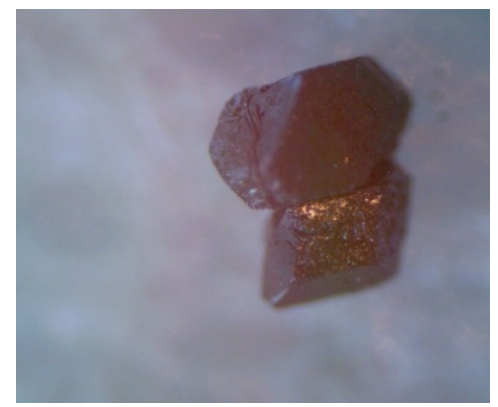

(a)

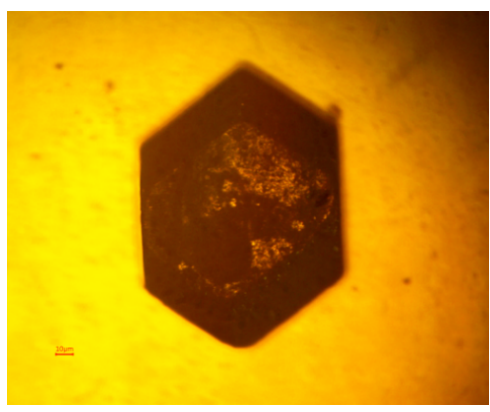

(b)

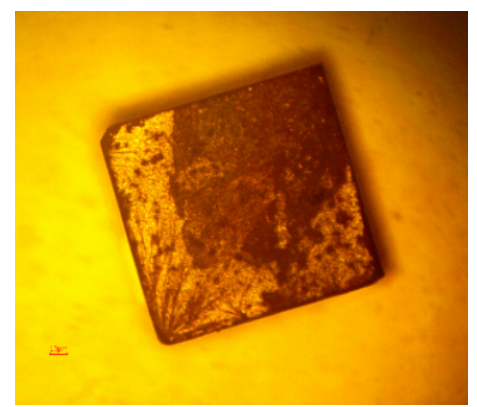

(c)

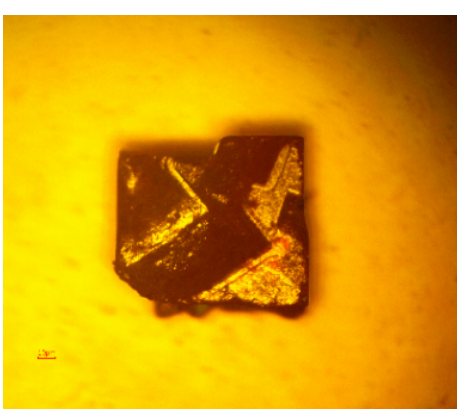

(d)

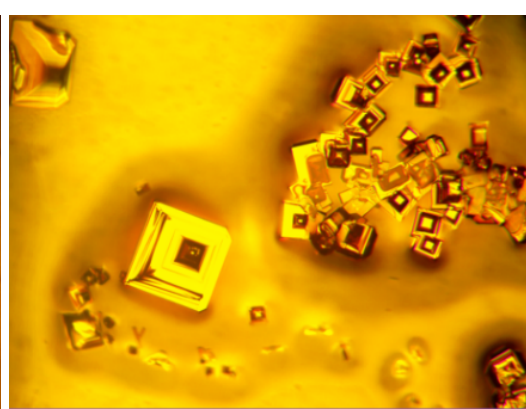

(e)

Fig. 2. The optical images of preparation formulas (a) $\mathrm{CH}_{3} \mathrm{NH}_{3} \mathrm{PbI}_{3}$, (b) $\mathrm{CH}_{3} \mathrm{NH}_{3} \mathrm{PbI}_{2} \mathrm{Br}$, (c) $\mathrm{CH}_{3} \mathrm{NH}_{3} \mathrm{PbIBr}_{2}$, (d) $\mathrm{CH}_{3} \mathrm{NH}_{3} \mathrm{PbI}_{0.25} \mathrm{Br}_{2.75}$ and (e) $\mathrm{CH}_{3} \mathrm{NH}_{3} \mathrm{PbBr}_{3}$ crystals with a magnification of $4 \mathrm{X}$.

In order to investigate the structure and the purity, the obtained material has been investigated by XRD measurements of the powder samples. SC-XRD measurements have also been carried out on well selected perovskite single crystals. Structural parameters of perovskites, deduced from the refinement of SCXRD data, are summarized in Table 2. The diffraction patterns in good agreement with simulated and literature data[15] correspond to the respective conformation of the perovskites structure: tetragonal for $\mathrm{CH}_{3} \mathrm{NH}_{3} \mathrm{PbI}_{3}$ as showed in Fig. 3, cubic for $\mathrm{CH}_{3} \mathrm{NH}_{3} \mathrm{PbI}_{2} \mathrm{Br}$ (Fig. 4), $\mathrm{CH}_{3} \mathrm{NH}_{3} \mathrm{PbI}_{0.25} \mathrm{Br}_{2.75}$ (Fig. 5) and $\mathrm{CH}_{3} \mathrm{NH}_{3} \mathrm{PbBr}_{3}$ (Fig. 6).

The difference of structures leads to the difference in the orientation of $\mathrm{CH}_{3} \mathrm{NH}_{3}+$. In the tetragonal structure of $\mathrm{CH}_{3} \mathrm{NH}_{3} \mathrm{PbI}_{3}$, according to the refinement of SCXRD data, the nitrogen atom is at the center, and the carbon is disordered in 4 different positions around the nitrogen atom. These positions are related through symmetry operations of $2 / \mathrm{c}$ (parallel to $\mathrm{b}$ axis) and 2 (parallel to c axis). In the cubic structure of $\mathrm{CH}_{3} \mathrm{NH}_{3} \mathrm{PbBr}_{3}$, the carbon atom and nitrogen atom are substitutionally disordered. Each atom is equally occupied 6 positions which are related through symmetry operations of 3 parallel to $[1,1,1]$ and inversion center resulting in 6 possible orientations of $\mathrm{CH}_{3} \mathrm{NH}_{3}+$ ion. This model is refined without adding hydrogen atoms. The methylammonium lead mixed halide perovskite (the preparation formula $\mathrm{CH}_{3} \mathrm{NH}_{3} \mathrm{PbI}_{2} \mathrm{Br}$ with the corresponding SCXRD refined formula $\mathrm{CH}_{3} \mathrm{NH}_{3} \mathrm{PbI} 1.69 \mathrm{Br} 1.31$, and the preparation formula $\mathrm{CH}_{3} \mathrm{NH}_{3} \mathrm{PbI}_{0.25} \mathrm{Br}_{2.75}$ with the corresponding SCXRD refined formula $\mathrm{CH}_{3} \mathrm{NH}_{3} \mathrm{PbI} 0.13 \mathrm{Br} 2.87$ ), 
has similar cubic structure in which halide ions are substitutionally disordered and occupied similar positions of bromide ions in $\mathrm{CH}_{3} \mathrm{NH}_{3} \mathrm{PbBr}_{3}$. Bonding situation of $\mathrm{CH}_{3} \mathrm{NH}_{3}+$ ion in these two perovskites is similar to that described in $\mathrm{CH}_{3} \mathrm{NH}_{3} \mathrm{PbBr}_{3}$.

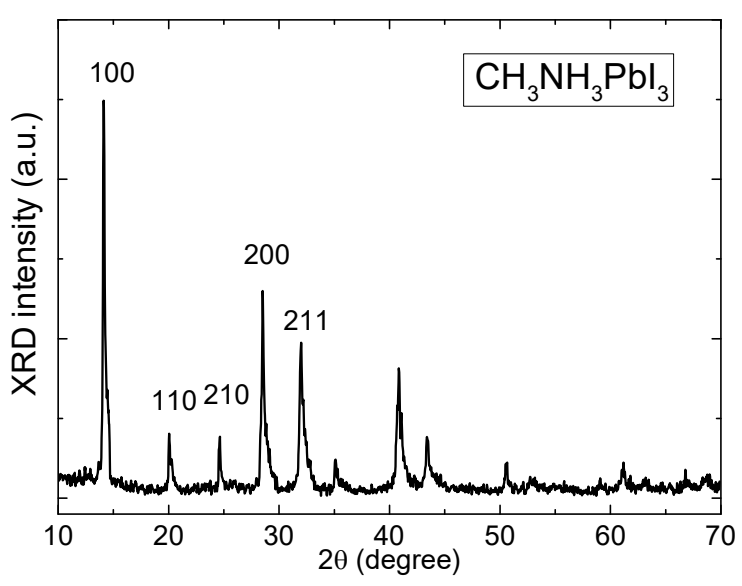

(a)

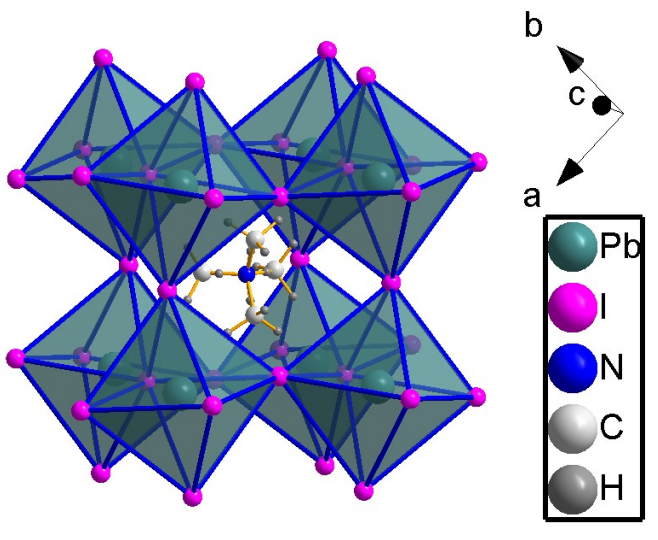

(b)

Fig. 3. (a) Experimental XRD pattern of $\mathrm{CH}_{3} \mathrm{NH}_{3} \mathrm{PbI}_{3}$ powder, and (b) corresponding SCXRD refined structure model of $\mathrm{CH}_{3} \mathrm{NH}_{3} \mathrm{PbI}_{3}$ single crystal with tetragonal structure. Four possible orientations of $\mathrm{CH}_{3} \mathrm{NH}_{3}+$ ion, related through different symmetry operations, are presented.

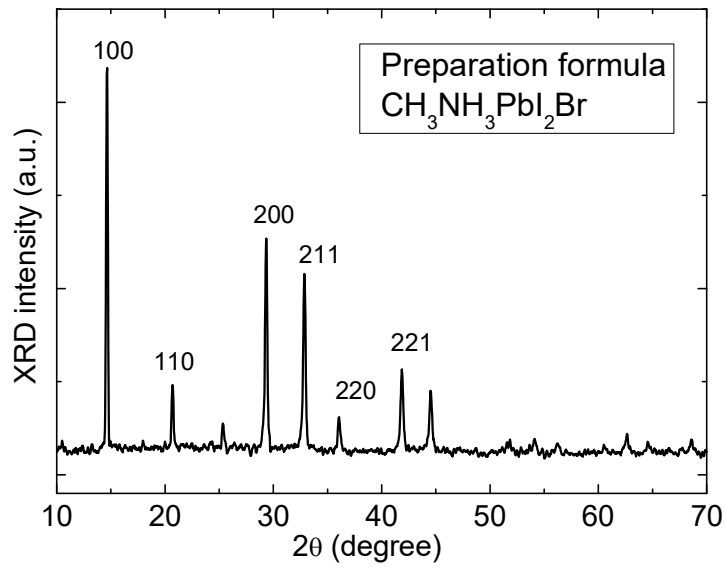

(a)

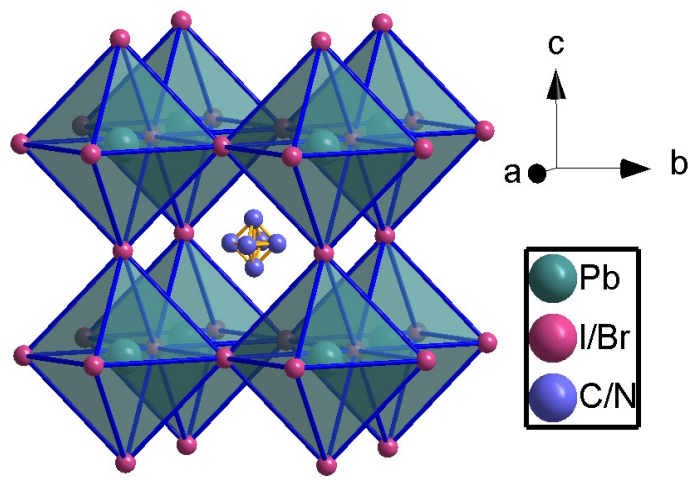

(b)

Fig. 4. Experimental XRD pattern of preparation formula $\mathrm{CH}_{3} \mathrm{NH}_{3} \mathrm{PbI} 0.25 \mathrm{Br} 0.75$ powder, and (b) corresponding SCXRD refined structure model of $\mathrm{CH}_{3} \mathrm{NH}_{3} \mathrm{PbI} 1.69 \mathrm{Br} 1.31$ single crystal with cubic structure. Six possible positions, equally occupied by $\mathrm{C}$ or $\mathrm{N}$, related through different symmetry operations, are presented. Hydrogen atoms were not added for the refinement. 


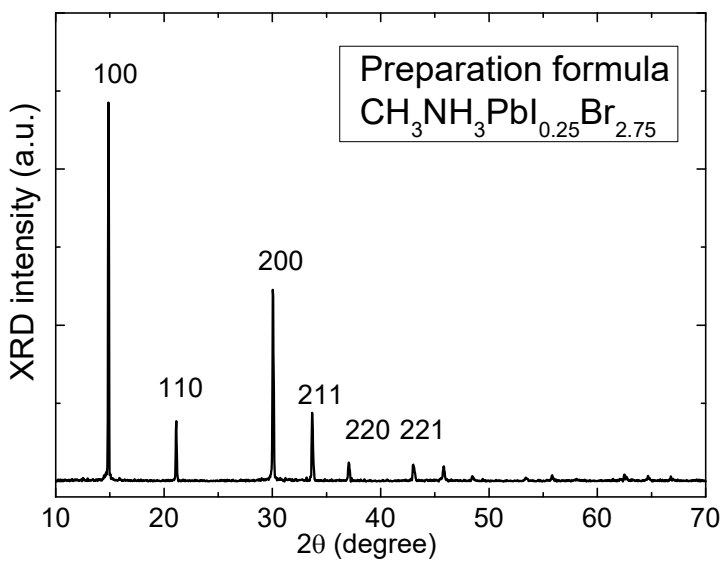

(a)

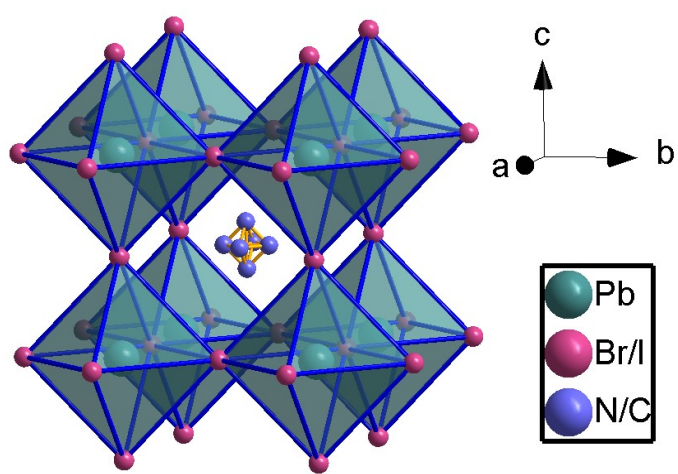

(b)

Fig. 5. (a) Experimental $X R D$ pattern of preparation formula $\mathrm{CH}_{3} \mathrm{NH}_{3} \mathrm{PbI}_{2} \mathrm{Br}$ powder, and (b) corresponding SCXRD refined structure model of $\mathrm{CH}_{3} \mathrm{NH}_{3} \mathrm{PbI} 0.13 \mathrm{Br} 2.87$ single crystal with cubic structure. Six possible positions, equally occupied by $\mathrm{C}$ or $\mathrm{N}$, related through different symmetry operations, are presented. Hydrogen atoms were not added for the refinement.

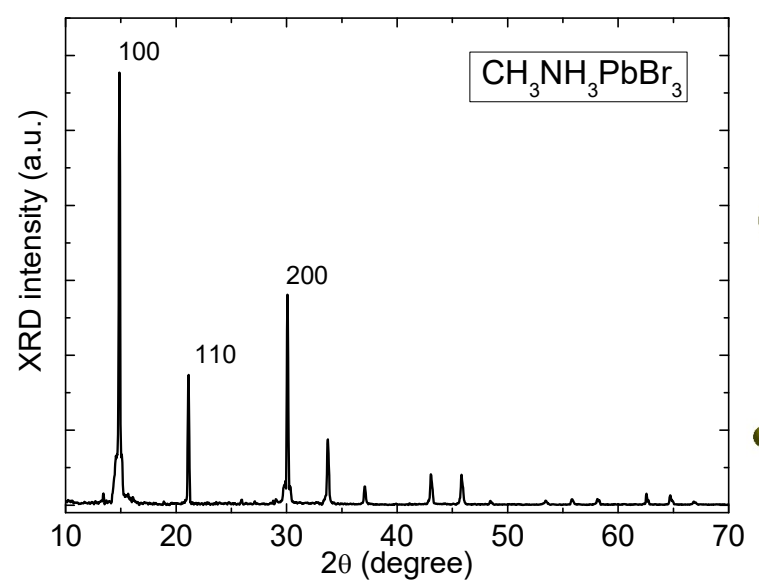

(a)

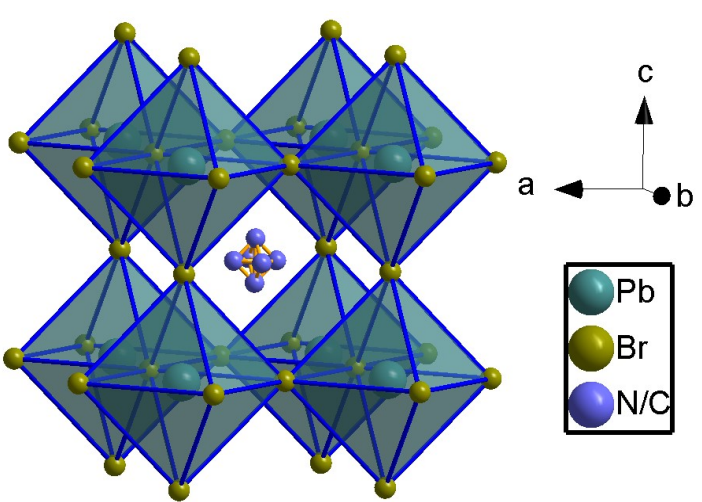

(b)

Fig. 6. (a) Experimental XRD pattern of $\mathrm{CH}_{3} \mathrm{NH}_{3} \mathrm{PbBr}_{3}$ powder, and (b) corresponding SCXRD refined structure model of $\mathrm{CH}_{3} \mathrm{NH}_{3} \mathrm{PbBr}_{3}$ single crystal with cubic structure. Six possible positions, equally occupied by $\mathrm{C}$ or $\mathrm{N}$, related through different symmetry operations, are presented. Hydrogen atoms were not added for the refinement.

Fig. 7 shows the comparison between the experimental XRD patterns taken on perovskite powder samples and the reconstructed XRD patterns from the results of SCXRD adjustment. The 
results suggest a good agreement between the experimental and simulation patterns, thus implying the correctness of lattice parameters shown in Table 1.

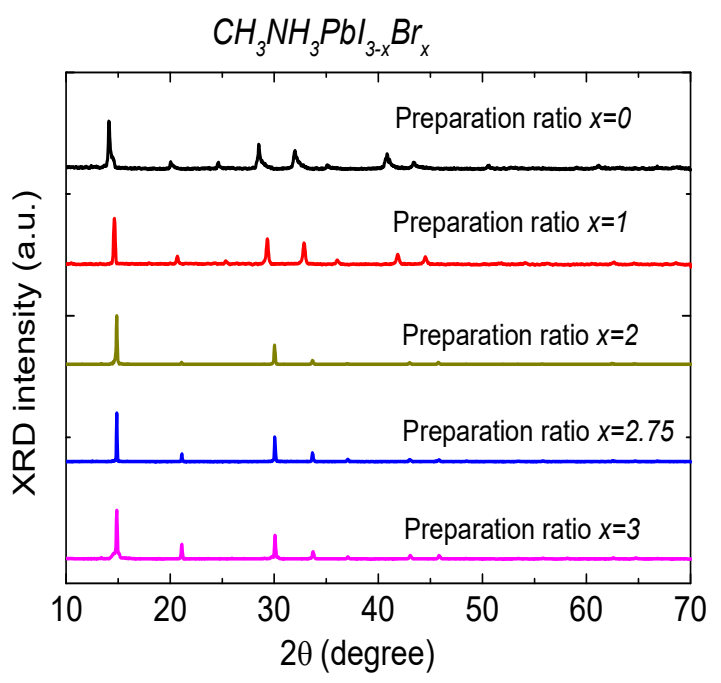

(a)

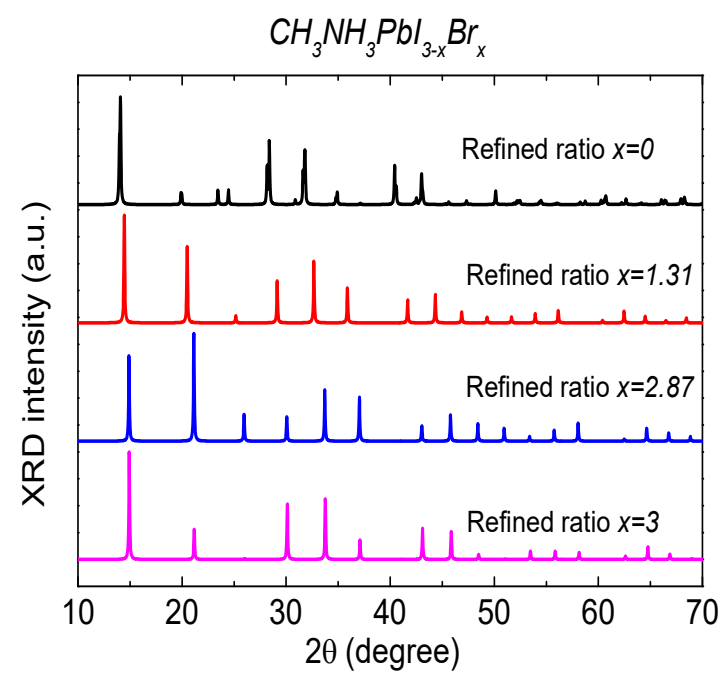

(b)

Fig. 7. (a) Experimental XRD patterns of $\mathrm{CH}_{3} \mathrm{NH}_{3} \mathrm{PbI}_{3-x} \mathrm{Br}_{x}$ powder, and (b) reconstructed powder XRD patterns from SCRXD analysis (note that the preparation ratio value $\mathrm{x}=2$ is missing).

\section{CONCLUSION}

In summary, we have successfully carried out the growth of bulk single crystals of methylammonium lead mixed halide perovskites $\mathrm{CH}_{3} \mathrm{NH}_{3} \mathrm{PbI}_{3-x} \mathrm{Br}_{x}$ by two methods: (i) inverse temperature crystallization and (ii) anti-solvent diffusion. The obtained $\mathrm{CH}_{3} \mathrm{NH}_{3} \mathrm{PbI}_{3-x} \mathrm{Br}_{x}$ single crystals have been characterized by optical microscope as well as single crystal and powder X-ray diffraction. The color of bulk single crystals changes from black to orange depending on the concentration of bromide element in the compounds. The X-ray diffraction confirmed the tetragonal structure for $\mathrm{CH}_{3} \mathrm{NH}_{3} \mathrm{PbI}_{3}$; and the structure became cubic with the bromide concentration higher than 1, starting from $\mathrm{CH}_{3} \mathrm{NH}_{3} \mathrm{PbIBr}_{2}$, even though the surface morphology of those single crystals exhibit parallelogram shapes. The single crystal X-ray diffraction analysis reveals the positions of lead and halide atom in the unit cell. The orientations of the organic cation $\mathrm{CH}_{3} \mathrm{NH}_{3}+$ in the unit cell are clearly resolved.

\section{ACKNOWLEDGMENT}

This research is funded by the Vietnam National University, Hanoi (VNU) under project number QG.17.26. 


\section{REFERENCES}

[1] M. A. Green, Y. Hishikawa, W. Warta, E. D. Dunlop, D. H. Levi, J. Hohl-Ebinger and A. W. H. Ho-Baillie, Prog. Photovoltaics Res. Appl. 25 (2017) 668.

[2] S. D. Stranks, S. D. Stranks, G. E. Eperon, G. Grancini, C. Menelaou, M. J. P. Alcocer, T. Leijtens, L. M. Herz, A. Petrozza and H. J. Snaith, Science 342 (2014) 341.

[3] O. Malinkiewicz, A. Yella, Y. H. Lee, G.M. Espallargas, M. Graetzel, M. K. Nazeeruddin, H. J. Bolink, Nat. Photonics 8 (2013) 128.

[4] G. Xing, N. Mathews, S. Sun, S.S. Lim, Y.M. Lam, M. Gratzel, S. Mhaisalkar, T.C. Sum, 'Long-Range Balanced Electron- and Hole-Transport Lengths in Organic-Inorganic $\mathrm{CH}_{3} \mathrm{NH}_{3} \mathrm{PbI}_{3}$ ', Science. 342 (2013) 344-347.

[5] G. E. Eperon, S. D. Stranks, C. Menelaou, M. B. Johnston, L. M. Herz, H. J. Snaith, Energy Environ. Sci. 7 (2014) 982.

[6] J. W. Lee, H. S. Kim and N. G. Park, Acc. Chem. Res. 49 (2016) 311.

[7] M. Xiao, F. Huang, W. Huang, Y. Dkhissi, Y. Zhu, J. Etheridge, A. Gray-Weale, U. Bach, Y.-B. Cheng, L. Spiccia, Angew. Chemie Int. Ed. 53 (2014) 9898.

[8] N. J. Jeon, J. H. Noh, Y. C. Kim, W. S. Yang, S. Ryu, S. Il Seok, Nat. Mater. 13 (2014) 897.

[9] J. Burschka, N. Pellet, S.-J. Moon, R. Humphry-Baker, P. Gao, M. K. Nazeeruddin and M. Grätzel, Nature 499 (2013) 316.

[10] W. Nie, H. Tsai, R. Asadpour, J.-C. Blancon, A. J. Neukirch, G. Gupta, J. J. Crochet, M. Chhowalla, S. Tretiak, M. A. Alam, H.-L. Wang, A. D. Mohite, Science 347 (2015) 522.

[11] Y. Yang, S. Feng, M. Li, W. Xu, G. Yin, Z. Wang, B. Sun, X. Gao, Sci. Rep. 7 (2017) 46724.

[12] D. Liu, L. Wu, C. Li, S. Ren, J. Zhang, W. Li, L. Feng, Y. Road, ACS Appl. Mater. Interfaces. 7 (2015) 16330.

[13] D. Shi, V. Adinolfi, R. Comin, M. Yuan, E. Alarousu, A. Buin, Y. Chen, S. Hoogland, A. Rothenberger, K. Katsiev, Y. Losovyj, X. Zhang, P.A. Dowben, O.F. Mohammed, E.H. Sargent, O.M. Bakr, Science 347 (2015) 519.

[14] M. I. Saidaminov, A. L. Abdelhady, B. Murali, E. Alarousu, V. M. Burlakov, W. Peng, I. Dursun, L. Wang, Y. He, G. Maculan, A. Goriely, T. Wu, O. F. Mohammed and O. M. Bakr, Nat. Commun. 6 (2015) 7586.

[15] Takeo Oku, Solar Cells - New Approaches and Reviews, InTech, 2015. 